${ }^{4}$ University of Wales Trinity Saint David, Swansea, United Kingdom

\title{
The Investment Attractiveness of the Agricultural Sector in Republic of Moldova in Terms of European Integration
}

\begin{abstract}
The modernization of the Agro-food sector, and revitalization of its conditions and standards, needs to attract funding sources from international donors, which helps stimulate the development of high value agriculture. Consequently, attracting agricultural investment is a strategic priority for Moldovan farmers, as this represents tangible economic growth based on retooling and modernization of agriculture. The National Bureau of Statistics ranks Moldova second in relation to the interest rates charged for loans. The average annual interest rate for lending to agriculture is $14.13 \%$. Georgia in first place with $29 \%$. Despite all the successes of banking, agriculture (as a sector) still remains an unattractive investment for banks in Moldova. The banking sector has also expressed reluctance in supporting small-scale agribusiness.
\end{abstract}

Key words: economic growth, investment attractiveness, investment environment, project financing, bank loans

JEL Classification: H41, L21, L31

\section{Introduction}

The investment process includes all the activities, works and operations performed over a period of time, including: training material; financial and human resources; information filtered through various factors, be they political, economic, financial; realization of social support; and the commissioning of economic objectives, social and otherwise. "Investment is the primary factor in national economic development strategy, all branches and industries, to increase revenue, and raise the standard of living" (Prelipcean 2001). Before investing, investors analyse the investment climate and investment potential of the state and its economic sectors, which reflects the attractiveness of the investment ("investment attractiveness").

The concept of 'investment attractiveness' can be formulated and applied to both an enterprise itself and across the sector. Being considered as normative it is used as a criterion for assessing the competitiveness of the sector (Analiza... 2018). Thus, the competitiveness of the national economy is determined by its investment attractiveness. In the process of research related to determining investment attractiveness, it is necessary to apply such categories as "investment attractiveness", "investment potential", "investment climate" and the interaction between them (Deryabina 2003). Investment attractiveness to potential investors reflects a subjective attitude towards the subject of investment. This differs from

${ }^{1}$ dr. hab., prof. univ. State Agrarian University of Moldova, 44, Mircesti st., MD-2049, Chisinau, Republic of Moldova, e-mail: e.timofti@uasm.md

2 e-mail: d.popa@uasm.md

3 e-mail: s.sasu@uasm.md

${ }^{4}$ e-mail: paul.osborne@uwtsd.ac.uk 
investment climate, which reflects the readiness of the social system, the ecological and economic situation of the investment process, and the investment objective.

Addressing the notion of investment climate can be defined as a measure of the investment process of economic units; of all social, economic, political, legal, institutional, and cultural premises which help determine the attractiveness and feasibility of investment in an economic system (Fetiniuc 2000). Although several authors from Moldova confirm that "further development (of the country) depends on effective components of the investment sphere," and most local economists support the idea that investments have a positive impact on economic development, the attractiveness of investment in the Republic of Moldova, including the agricultural sector, tends to decrease. This is due to an increasing number of factors that reduce the investment attractiveness of the country (Hincu, Suhovici 2007).

The main factors that make Moldova attractive for foreign investment are:

The advantageous location of the country - ait is a link between the East and West and also has a favourable geographic location in the centre of Europe.

Fertile soils $-80 \%$ of the territory is in the Chernozems. Moldova is rich in fertile soils which produce wine, fruit and meat. Moldova also has opportunities for ecologically clean production of goods. It is therefore suggested that agriculture is one of the areas that would most interest foreign investors.

Relatively cheap skilled labour - Moldova has a skilled labour force, available at much lower labour cost than in many other European countries.

The factors contributing to the decrease in the investment attractiveness of Moldova:

Dependence on the economy of energy resources - There has been limited foreign investment in domestic-oriented sectors. Stopping the supply of oil and gas will lead to halting economic growth, which will in turn lead to the reduction of the country's attractiveness for foreign investors.

Instability and an insecure legislative basis - The instability of the legislative base is characterized by a high risk of changes in legislation and changes in economic and legal mechanisms of regulation by the state. It is important that laws and decisions of the state, once adopted, are respected and followed.

The low levels of business culture to investors - investors are faced with inefficient management, insufficient knowledge and outdated management methods.

Distrust of the banking system - low efficiency of other elements of the domestic financial market (insufficient development of the securities market, insurance companies, and the pension funds). Currently, banks in Moldova are not considered serious institutions to finance the economy because their resources are reduced and expensive.

\section{Materials and methods}

Sources of analysis included information of the Ministry of Agriculture, the Agency for Payments and Intervention in Agriculture, Ministry of Finance, the financial statements of commercial banks and other financial bodies and domestic economic data, including statistical directories NBS in Moldova and abroad (Posibilită $\square$ i..., 2018).

The basic methods of research are: observing and comparing, the average size and relative time series method. 


\section{Results and discussions}

Moldova is actively seeking foreign direct investment (FDI). Granting loans for agricultural purposes requires long-term investing in high performance machines, irrigation equipment, adequate space for increasing livestock, maintenance efforts in food supply, and much more, all of which should be aimed at increasing production.

Moldova Agroindbank is currently (at the time of writing) the leader in the agribusiness sector, with $19.7 \%$ of total loans in Lei, and $23.2 \%$ in foreign currency, given the sector. A limiting factor in lending to the agricultural sector is the National Bank and regulations that limit the concentration of loans to a single sector to $25 \%$ of the total loan portfolio. However, as mentioned, only Moldova-Agroindbank amongst all commercial banks domestically is approaching the limit for credits to agriculture and the food industry.

This may explain why in European countries, agricultural enterprises can expand their business by implementing modern technologies that not only increase the yield per hectare and permit the production of quality products, but also improve the working conditions of farmers, thus contributing to improving their quality of life.

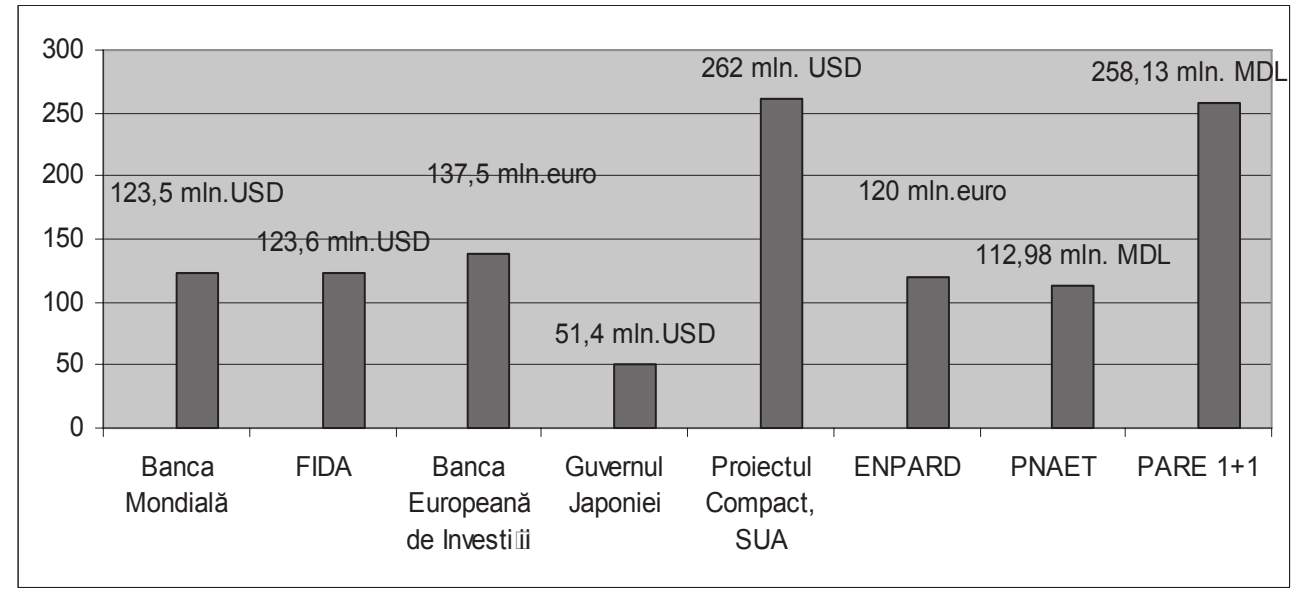

Fig. 1. Investment Projects in the Agrarian Sector of the Republic of Moldova during 2000-2014

Source: Ministry of Finance based on information (Annual Report, 2015; National Strategy for Agricultural and Rural Development for the years 2014-2020).

In 2010, the "Compact Agreement" entered into force, which provided a grant of $\$ 262$ million to Moldova by the US government through the Millennium Challenge Corporation (Figure 1). This project is accessible exclusively for agricultural producers and producer groups, cooperatives, associations, exporters and other stakeholders in the agricultural value chain: Criuleni, Orhei, Anenii Noi, Dubasari, Nisporeni, Ungheni, Leova and Cahul. Currently, several irrigation systems in Ungheni, Nisporeni, and Leova are being rebuilt or revived, with a total investment of $\$ 66$ million (9,300 ha irrigated arable land); an irrigation system in Cosnita - \$8 million (2400 ha) and an irrigation system in Chircani-Zîrneşti $\$ 13$ million (2200ha). During 2015, 11 irrigation systems were planned to be put into operatio, $\mathrm{n}$ with the ability to serve $15 \mathrm{mii}$ ha of agricultural land in these districts $(3,000$ farms) (O misiune...). 
The initial reform of the irrigation sector also includes a loan program for post-harvest infrastructure investments which is worth 12 million USD. The funds are accessed by farmers in the districts mentioned above, but also from other districts of Moldova. Destination loans are offered by the Compact towards the purchase or construction of cold storage (including refrigerating equipment) and buying adjacent land, purchase of equipment for the processing and sorting of fruits, vegetables and grapes and procurement of laboratory equipment for quality control. So far, 21 loans have been disbursed, totalling 4.3 million USD, including 16 loans totalling approximately $\$ 3.2$ million, re-invested in the construction of cold storage for fruit, vegetables and grapes with a total capacity of about 16,500 tonnes (O misiune...).

In 2014 the "Compact" Loan Program was launched to facilitate farmers' access to financing. Changes were introduced to allow investment in post-harvest infrastructure and high value agriculture. Thus, entrepreneurs can now apply for loans for the construction or purchase of vegetable greenhouses, equipment and/or land related to these greenhouses, irrigation equipment, the purchase of new weather stations and, when necessary, new farms. "Compact" loans are granted to establish plantations of fruits, berries and grapes or nurseries of fruit trees, grapes and berries. Changes have been made to the conditions for granting loans, reducing the minimum amount of credit from 20,000 USD down to 5,000 USD (or equivalent in Lei or Euro). The "Compact" maximum amount of loans remains unchanged $-600,000$ USD, and the deadline for offering the loans is 3-7 years. This change will allow smaller agricultural enterprises to benefit from loans for business development.

Since the project was launched in the year 2000, IFAD, Project Rural Financial Services and Agribusiness Development (which comprises a portfolio of five programs) has provided about 70 million USD in loan funds. The volume of investments in agriculture through the IFAD Programme in the period 2001-2016 exceeded 123 million USD. Projects under IFAD loans are issued through participating financial institutions namely: Moldova Agroindbank, Energbank, Moldindconbank, Victoriabank, Mobiasbanca-Groupe Societe Generale (Rural...).

So far, with this background, 1994 hectares of fruit trees and 1518 hectares of vines were planted in Moldova. Seventy cooling systems units with a capacity of over 30,000 tons and 327 units of agricultural machinery were also acquired, including tractors and combines. Among the beneficiaries of these investments may include "Gospodarul Rediu" LLC Falesti, SoroAgro "SRL in Edineti" Vindex-Agro "Ltd of Orhei" Podgoreni "SRL Cantemir (Rural...).

For the period from 2014-2020, a new program of Rural Economic Climate Resilience Inclusive (IFAD VI) with a budget of 26.08 million USD has been created. The Program aims to enable poor rural entrepreneurs to increase revenue and strengthen resilience: to improve farmers' ability to adapt to climate change; to increase access to credit for rural population by providing appropriate and affordable financial products; to increase productivity and competitiveness, to increase investment, and improve market access (Programul...).

In 2014, the Ministry of Agriculture and Food Industry, along with the Consolidated Implementation and Monitoring Agricultural Project (CAPMU) - the agency responsible for coordinating the preparation of projects, managing all projects implemented by the World Bank's agriculture and rural affairs areas - launched two grant programs for producer farmers under the "Competitive Agriculture in Moldova" (MAC-P), with a duration of five years (2013-2017). 
Grants programs are made by MAFI and have a budget of 28.4 million USD. Grants and investment projects aim to strengthen the competitiveness of the agro-food sector in Moldova by supporting the modernization of state food safety management systems, easing access of farmers to markets and agricultural practices and integration of environmental and sustainable land management. The beneficiaries of these projects can receive grants of 50\% of total investment (up to 350,000 USD for a producer) for the purchasing of technological equipment and post-harvest equipment (sorting, washing, grading, packing, drying, etc.). The sources are available through International Agency for Agricultural Payments.

Another project financing initiative conducted by the World Bank in 2014, was offering 45 million USD for Project Competitiveness Enhancement II (CAP II), which will help enhance export competitiveness and reduce the regulatory burden for agricultural enterprises in Moldova. According to information on investment projects managed by the Credit Line Directorate (DLC), from the commencement of the initial period of implementing investment projects for development of small and medium enterprises, about 6773 sub-projects of the beneficiaries, mainly in rural areas, were financed in the sum of 2113.2 million Moldovan Lei (MDL), 88.96 million USD and 38.08 million Euros (or the equivalent of about 3.82 billion MDL) (Strategia...).

The purpose of these projects is the revitalization of the agricultural sector in Moldova, creating new jobs and generating income for the rural population. The grant loans for the sub-allocated to final beneficiaries by IFP (Participating Financial Institutions) are 172.92 million MDL and 0.89 million USD.

The National Programme for Economic Empowerment of Youth PNAET is a program for young people who want to develop their entrepreneurial skills to start or expand a business in agriculture or manufacturing. The program duration was from 2008 to 2013 . Thus $82.44 \%$ of loans in the PNAET Program were placed in the agriculture and food industry. The funds were granted to beneficiaries for the purchase of new production equipment and machinery, of which 537 sub-projects $(75.21 \%)$ were granted to new enterprises which were created; 177 subprojects $(24.79 \%)$ for the development of existing businesses. Under PNAET the following items were procured: 395 tractors. -312 ; units of agricultural equipment and other machinery including computers for consulting services in agriculture. The most active geographical region in terms of pulling in funds from the PNAET Program is the Northern region of the country with 421 sub-projects or $59.84 \%$ of the total number of sub-projects awarded, followed by the Central region with 149 sub-projects or $20.57 \%$ and the South with 144 sub-projects or $19.59 \%$ as all participating municipalities (Raport...).

The European Investment Bank ("EIB") also finances wine through the Wine Sector Restructuring Programme "Wine Branch" of Moldova. Loans amounting to less than 25 thousand Euros (wine for any activity) and no more than 5 million Euros. EIB financing equates to $50 \%$ of the investment project, the second $50 \%$ of the project investment is in the form of cash and/or material goods.

In the period 2016-2020, horticultural businesses will benefit from a loan of 120 million Euros, provided by the EIB. The contract for funding the project "Moldova Orchard" has a value of 120 million and has been offered to Moldova for a period of 10 years and has an implementation period of 5 years. The interest rate for the loan is expected to be between $4.5 \%$ and $5.5 \%$ annually. The project aims to modernize and restructure the horticultural sector value chain, including investment in technology and equipment with health institutions responsible for certification and accreditation for the testing of products. It also will focus on quality education in the field including marketing and promoting new 
markets. An innovation project "Orchard Moldova" will be available through leasing companies. Opening leasing transactions which, unlike Credit Classic, does not require collateral, provides greater opportunities for young entrepreneurs. The project will access 500 of the largest beneficiaries and about 30 thousand farms (O misiune...).

During 2000-2012, the project of Japanese Assistance for Underprivileged Farmers (2KR) with a budget of 22.9 million USD was announced. The overall objective of the project was to increase food production in Moldova by reducing crop loss and improving the quality of basic measures in the preparation of the soil. In total, through this project until 2012, Moldovan farmers received 6,500 units of agricultural machinery, averaging four pieces for every village in the country.

Government Decision no. 972 of $18^{\text {th }}$ October 2010 approved a Pilot Program for Attracting Remittances in Economics ("PARE $1+1$ ") for 2010-2012. The Program objective was to inform and train migrant workers in entrepreneurship, contributing to the reintegration of migrants by mobilizing human and financial resources of Moldovan migrant workers in the sustainable economic development of Moldova and stimulating the establishing and development of small and medium enterprises. In 2010-2012, through the Programme, investments of over 76 million Lei were made in the national economy. The "PARE 1 + 1" has been extended until 2014 and then, as per Government Decision 866 of 12.18.2015, the program was extended until 2018 (Programul-pilot...).

Through the PARE $1+1$ program, over 700 companies have been funded in the country and opened up more than 120,000 jobs in Moldova. The total investment program beneficiaries of "PARE $1+1$ " is 258.13 million Lei. The grant supported beneficiaries equal 76.66 mil Lei. Studies have shown that migrant workers invested their resources abroad, which was accumulated primarily in agriculture - 58\%, followed by manufacture/processing $-20 \%$, services $-18 \%$ and food $-3 \%$ (Programul-pilot...). Analysing the data in Figure 2 (below), it is suggested that during 2007-2014 the main source of investment for the agricultural sector were loans obtained from commercial banks amounting to 15.200 million Lei.

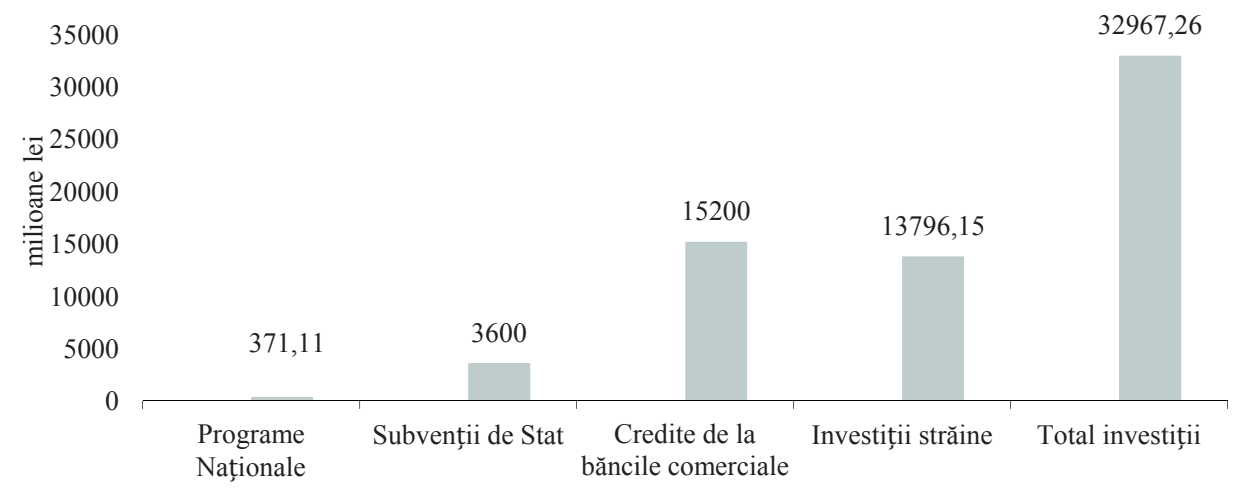

Fig. 2. The investment in the agricultural sector of Moldova during 2007-2014 in million Lei

Source: based on Annual reports of the National Bank of Moldova (Analysis activity of lending AB Moldovan commercial banks, 2013 year). 
Foreign investments in the period under review decreased by 8.32 million Lei. The investments of National Programs were just over 371 million Lei and accounted for only $2.68 \%$ of the foreign investment.

With the initiation of the liberalization of trade with the European Union, domestic farmers have begun to face a very strong competition with farmers in the European Union and will have to comply with the new requirements in terms of developing a business in agriculture. The remaining products not listed in these two categories can be exported to "zero tax".

The signing of the Agreement on free trade with the European Union impacted $91 \%$ of the domestic products in the European market. Meanwhile, import duties on meat products, dairy products and sugar in Moldova will continue being phased out gradually, in stages ranging from one or two products over 3-10 years. Lending to agribusiness is characterized by very high interest rates and lengthy procedures, and the requirements of commercial banks regarding collateral are exaggerated. In these circumstances, agrarian entrepreneurs may not receive sufficient funding and the adequate development needs of their business. State institutions must be more active in attracting foreign technical assistance as external donor technical assistance, which can be an important factor boosting modernization for the agro-food sector and structural organization of the main value chains. Despite all the successes of banking, agriculture as a sector still remains an unattractive investment for banks in Moldova. The banking sector has also expressed reluctance in supporting small scale agribusiness. Indeed, our research does not indicate a fierce competition between banks regarding this potential banking product offer. According to creditors, few farmers present a viable business plan that would guarantee a refund. The strong influence of climatic conditions also makes agriculture lending a risky area for banks, not only in Moldova but anywhere in the world.

\section{Conclusions}

1. The research reveals that economic modernization and improvement of the agricultural sector in Moldova by attracting additional investment is one of the main directions for increasing efficiency, productivity and creating jobs in rural areas. The economic sector, considered as a separate system, is influenced by a multitude of restrictions, conditions of indigenous origin and politics (external).

2. It makes sense that taxes and appropriations are made as effective levers of economic growth and development of the agricultural sector. Their shares must be available for businesses; the cost of loans contracted from commercial banks must turn into a profitable source of funding. The modernization of the Agro food sector and revitalization of the conditions and standards needs to attract funding sources from international donors which in this way stimulates the development of high value agriculture.

3. Based on the analysis, it was found that the implementation of investment projects in the country's agrarian sector through the Credit Line Directorate administered through the World Bank, IFAD, European Investment Bank, the Government of Japan, the project Compact (USA) ENPARD, PNAET, PARE $1+1$ are very important and are considered as a form of support to agricultural producers in Moldova from the state, to the ultimate goal of revitalizing the agricultural sector, creating new jobs and generating income for people in the agricultural sector. 


\section{References}

Analiza activității de creditare a băncilor comerciale din Republica Moldova (Analysis of lending activity of commercial banks in the Republic of Moldova) (2018). Available 25.03.2018 from: http://www.bank.md/ analiza/Analiza \%.

Buletine informative (Newsletters). Available 25.03.2018 from: http://www.irigare.md/?page=publicatii\&lang=1\& $\mathrm{e}=50$.

Cadrul Național Strategic pentru Dezvoltarea Durabilă a Spațiului Rural Românesc 2014-2020-2030. (2013) (National Strategic Framework for Sustainable Development of the Romanian Rural Area 2014-2020-2030). CNS. Available 25.03.2018 from: http:/eufinantare.info/docs/analiza-dezvoltarii-rurale-agricultura-iulie2013.pdf.

Fetiniuc, V. (2000). Bazele metodice de evaluare a climatului investițional (Methodological Basis of Investment Climate Assessment). Revista Enonomie și Finanțe, 11, 62-67.

Deryabina, Y. (2003). Comparative analysis of approaches to assessing the investment attractiveness and investment activity of Russian regions. Investments in Russia, 8, 9-19.

Hincu, R., Suhovici, A. (2007). Unele probleme ce țin de investirea în economia autohtonă si căile de soluționare a acestora (Some issues related to investing in the local economy and ways to solve them). Revista Economica 1(57), 61-64.

Prelipcean, G. (2001). Restructurare si dezvoltare regională. Editura Economică (Restructuring and Regional Development), București.

Programul Rural de Reziliență Economico-Climatică Incluzivă (Rural Rural Inclusive Economical and Climate Resilience Program) (IFAD VI). Available 25.03.2018 from: http://www.ifad.md/programs/dejstvujushhieprogrammi/Programul-Rural-de-Rezilien-Economico-Climatic-Incluziv-IFAD-VI/;25.03.2018

Posibilită $\square$ i de finan $\square$ are (Funding opportunities). Available 25.03.2018 from: http://maia.gov.md/ro/categorii/ posibilitati-de-finantare.

Programul-pilot de Atragere a Remitențelor în Economie (PARE 1+1) (Pilot Program for Removing Remittances in the Economy). Available 25.03.2018 from: http:/www.mec.gov.md/ro/content/programul-pare-11; http://www.odimm.md.

Rapoarte anuale ale Băncii Na $\square$ ionale a Moldovei (Annual Reports of the National Bank of Moldova). Available 25.03.2018 from: https://www.bnm.md/ro/tipuri-de-publicatii/raport-anual

Raport Directoratului Liniei de Credit pe lângă Ministerul Finanțelor privind utilizarea resurselor de recreditare în cadrul Programului de Abilitare Economică a Tinerilor (Report to the Directorate of the Credit Line to the Ministry of Finance on the use of re-crediting resources within the Youth Empowerment Program). Available 25.03.2018 from: http://mts.gov.md/docs /2010/Raport-PNAET.pdf.

Rural Financial Services and Agribusiness development project. Available 25.03.2018 from: http://ifad.md/files/ filemanager/file/rapoarte/ifad_v_annual_report_2012.

Strategia Na $\square$ ională de Dezvoltare Agricolă $\square$ i Rurală pentru anii 2014-2020 (National Strategy for Agricultural and Rural Development for the years 2014-2020). Available 25.03.2018 from: lex.justice.md/md/353310.

O misiune BEI anun $\square$ ă lansarea proiectului "Livada Moldovei" (An EIB mission announces the launch of the "Livada Moldovei" project). Available 25.03.2018 from: http://winemoldova.md/event.php?id=143\&lng=ro.

\section{For citation:}

Timofti E., Popa D., Petrascu S., Osborne P. (2018). The Investment Attractiveness of the Agricultural Sector in Republic of Moldova in Terms of European Integration. Problems of World Agriculture, 18(3), 315-322; DOI: 10.22630/PRS.2018.18.3.89 